\title{
THE EFFECT OF MODIFIED FREE INQUIRY APPROACH ON STUDENT'S PROCESS SKILL AND SCIENCE ATTITUDES
}

\author{
Kholilurrohman $^{1 *}$, I Gusti Putu Suryadarma \\ ${ }^{1}$ Postgraduate Program, Yogyakarta State University \\ Corresponding Author. Email: kholilurrohmanabhaz@yahoo.co.id
}

\section{Keywords: \\ Modified Free Inquiry, Guided Inquiry, Science Process Skill, Science Attitude}

\begin{abstract}
This study aims to determine the effect of Modified Free Inquiry approach on student's process skill, and student science attitudes. This Quasi-Experimental study used pretest-posttest with nonequivalent control group design with grade XI student's of MAN Maguwoharjo Yogyakarta in the second semester of academic year 2012/2013 as a population, and used 2 classes of XI Science Programs as a sample group. This approach is implemented on biology learning through human sense system matters. Learning in this study lasted for 6 times meetings for each group of samples, and the data were obtained by data collection instruments in the forms of a written multiple choice test for science process skill, observation sheets for scientific process skills and science attitudes, and a questionnaire for science attitudes which was administered before and after learning. The data were processed with IBM SPSS 20 software for windows, and hypothesis testing was done through multivariate analysis. The results of the study show a significant value of 0.000 , which mean there are significant effect of Modified Free Inquiry approach on: (1) Student's science process skill, and (2) science attitudes, if it's compared with Guided Inquiry approach.
\end{abstract}

\section{INTRODUCTION}

Science learning should be implemented with an approach that emphasizes the experience of students to directly deal with natural phenomena through activities based on scientific performance. Students are often overburdened with the usefulness of learning the facts and underlined terms by ignoring the importance of being active in practicing science. The latest research results support the statement that students will learn very well when actively involved, both physically and mentally, in practical activities and thinking. Hands-on activities will lead students to mind-on understanding when educators are able to combine the two with a number of structured big ideas and when students have the opportunity to think about everything that should be done (Rezba, et. al, $2007: 4$ ).

Inquiry is a method used by a science educator to teach material in front of the class that is done by giving students the opportunity to research a problem so they can find a way to solve it (Hardini \& Puspitasari, 2012: 152). Application of inquiry in learning has the benefit of returning the idea of an inquiry framework 
that can be implemented in science classrooms at all levels so as to increase students' deepening with a variety of content and with epistemic exercises / practices on authentic science (Chabalengula, Mweene \& Mumba, 2012: $2)$. The scientific inquiry approach has three types of implementation; first, Guided Inquiry (Guided Inquiry), where most of the planning is made by educators and students do not formulate problems.

Guided Inquiry is suitable for students who still do not have much experience to carry out investigative actions (Sund \& Trowbridge, 1973: 67-68). Second, modified free inquiry (Modified Free Inquiry), students who are planned to conduct learning with the Modified Free Inquiry approach are supported to be able to solve problems according to their own or group's abilities. The existence of an educator is only as someone who gives a little help to ensure students do not experience frustration / hopelessness or so that students do not gain experience that is too often mistaken. Assistance that may be provided by educators in the form of questions to stimulate students' thinking power related to investigative procedures that can be done (Sund \& Trowbridge, 1973: 72). In this inquiry learning educators provide problems or problems and then students are asked to solve these problems through observation, exploration, and research procedures. The third scientific inquiry approach is free inquiry. This approach occurs when students initiate and carry out their investigative power (Sund \& Trowbridge, 1973: 71), students conduct independent research as a scientist. In this learning, students must be able to identify and formulate a variety of topics to be investigated.

Scientific attitudes in learning science are often associated with attitudes toward science. Both are interconnected and both affect actions. A positive attitude towards learning science will make a high contribution in the formation of scientific attitudes (Bundu; 2006; 139). One of the goals of developing a scientific attitude is to avoid the emergence of negative attitudes in students such as feelings of failure before doing a task.

The development of scientific attitudes and interests is not an option that can be ruled out. To replace the effort to carry out relevant activities in daily teaching, it must originate from a significant area of life by overcoming false ideas and misconceptions. Science educators must be interested in developing students' scientific attitudes. Fragment changes related to the science curriculum must be consistent with the intention of developing scientific attitudes of students (Pillai, 2012: 32). The attitudes analyzed in this research are Honesty, Curiousity, Open-minded, and Skepticism.

Results of initial observations and interviews in the class XI environment of MAN Maguwoharjo Sleman Yogyakarta, the inquiry approach is still unfamiliar to both educators and students. However, there is a method that approaches the steps in the implementation of the inquiry approach, namely practicum / laboratory observation activities. The procedure of practicum / laboratory observation conducted by the teacher / educator supporting the subject is similar to the Guided Inquiry approach which is the control group in this study, whereas in this study itself, the type of approach implemented as a treatment group is the Modified Free Inquiry that will be observed its effect on the process skills and scientific attitude of students in class XI IPA MAN Maguwoharjo Yogyakarta on the material of the sensory system in humans in the academic year 2012/2013.

Some of the results of the initial observation activities also show that educators still often act as sole informants in delivering learning material, both by lecturing, demonstration, and so on. Therefore it is necessary to choose a learning approach that does not take place in one direction, is more varied and is able 
to bring students closer to discover science concepts independently.

The students of class XI IPA MAN Maguwoharjo lack a role in the learning process, so aspects of the science process skills have not been implemented properly. Therefore, we need an approach that puts forward the process of scientific performance that can cause students to gain knowledge through experience in managing ideas that arise from within and change students to become more active in learning.

Scientific attitudes of students have not been well observed by educators, so educators need to implement a learning that is able to manage the positive behavior of students in dealing with biological science phenomena.

MAN Maguwoharjo has good conditions for applying the Modified Free Inquiry approach. One of the hopes and benefits of implementing inquiry-based learning is that there is a learning process that takes place not one

\section{Research Methods \\ Types of research}

This research is a quasi-experimental type and has a pre-test post-test design with non equivalent control group.

\section{Time and Place of Research}

This research was conducted in the even semester of the academic year 2012/2013 in class XI IPA MAN Maguwoharjo Depok District Sleman Regency D.I. Yogyakarta.

\section{Research Targets / Subjects}

The population in this study were students in class XI MAN Maguwoharjo Yogyakarta, while the sample was in the form of class XI science students. For several reasons, two classes were used as research subjects, namely class XI IPA 1 as the treatment class with the Modified Free Inquiry approach, and class XI IPA 2 as a control class by applying the Guided Inquiry approach. This study is a sample study, because the results of research on groups of individuals who become the sample are also applied to other individuals who are included in the population group Determination of the sample is done without any randomization process. This is done solely for the treatment of the types of approaches implemented in learning, and does not aim to discriminate the sociocultural aspects in the sense that a sample group is considered superior compared to other sample groups.

\section{Procedure}

This research which has a pre-test design with a non-equivalent control group begins with analyzing the feasibility of aspects of the process skills and scientific attitude of students first, followed by giving treatment to each sample group, which in this case is an approach in learning based inquiry, and concludes by analyzing aspects of process skills and scientific attitudes again after the implementation of the learning approach is implemented.

This quasi-experimental study was used to test the effect of the Modified Free Inquiry approach as a treatment group, and learning with the Guided Inquiry approach used as a control group.

\section{Data, Instruments and Data Collection Techniques}

Data on aspects of science process skills of students are collected by test and non-test techniques. The test technique is given in the form of science process skills test for students in the form of a multiple choice test / multiple choice test with 4 items of alternative answer choices (A, B, C, and D). The points of science process skills tests are given before (pre-test) and after (post-test) both types of learning are implemented (with the Modified Free Inquiry and Guided Inquiry approach). The form of the test items have the same lattice, but differ in terms of the material content of the sensory system in humans in biology learning for this class XI Science.

Non-test techniques are also applied to analyze aspects of process skills that have 
not been quite perfect obtained through test techniques. Non-test technique for this process skills in the form of observation sheet in the form of a checklist that supports the achievement of the implementation of a number of aspects of the observed process skills. This technique is also applied before and after learning.

Data on aspects of scientific attitudes of students are only obtained through non-test techniques. Data on aspects of scientific attitudes is obtained through the observation sheet of scientific attitudes and the scientific attitude questionnaire as its supporting capacity.

The test used in this study is a multiple choice test consisting of 20 items that have been analyzed in terms of validity and reliability before being implemented in learning activities. This test is in the form of a series of questions consisting of four answer choices used to measure students' science process skills in both the treatment class and the control group. Each correct student answer is given a score of 1 , while an incorrect answer gets a score of 0 .

Data collection method with this test method is divided into two stages, namely pre-test and post-test. Pre-test is a number of written questions asked to students to determine the conditions and initial knowledge before the learning approach related to the material system of senses in humans is conveyed. While Post-test is a series of written questions that are submitted to students after the learning approach and all teaching material has been submitted to students. This post-test can also be used to find out teaching material that has been successfully absorbed and mastered well by students.

The observation method used in this study has a function to determine the science process skills and scientific attitudes of students during the biology learning process. The method of observation is to collect data by directly observing and systematically recording the phenomena under investigation. This method is used to involve directly up close the activities of learning Biology of the Indra Tool System. The observation sheet instrument in this study was a checklist used when biology learning was taking place. Students' scientific performance and attitude are observed with the help of an observer without reducing the time of the implementation of learning activities.

Questionnaire referred to in English as "questionnaire" is a method of data collection which is done by giving a set of written questions to students who become samples / respondents to know the responses / affective responses while following the biology learning process on the material of the sensory system in humans, both with the Modifiied Free Inquiry approach to the treatment class and the Guided Inquiry approach to the control class.

The questionnaire sheet used as an instrument of this research is a Likert scale for response scale 4, namely a number of statements followed by columns indicating levels, for example, from often to never. The multilevel answer category used in this questionnaire produces data in the form of a checklist obtained from the responses of students on the questionnaire answer sheet, is always (S), often (SR), rarely (J), never (TP). Answer categories have graded scores, namely: 1, 2, 3, and 4. for positive statements the answer category always (S) scores 4, often (SR) scores 3, rarely (J) scores 2 and for answers never (TP) gets a score of 1 . For negative statements the score is reversed, from the category of never (TP) to always (S) scores from 1 to 4.

\section{Data analysis technique}

Descriptive analysis techniques are used to analyze the characteristics of respondents who have been studied. In this study, this technique is used to describe data in the form of pre-test and post-test scores, as well as students' response scores in following the process of learning the biology of the human sensory system. Also 
to describe the data from research observations. This descriptive statistical calculation is done with IBM SPSS 20 software for windows.

Testing the analysis prerequisites is very necessary in research, in this case, the analysis prerequisites are carried out to determine and determine the homogeneity and normality of the sample groups used. The prerequisite test of this analysis was carried out before the implementation of the Modified Free Inquiry approach to the material of the Indra Tool System in Humans in the learning of Biology Science Class XI IPA MAN Maguwoharjo Sleman Yogyakarta.

Homogeneity test is performed to find out whether a treatment or control group has the same variance or not. This homogeneity test uses the Levene test which was carried out with the help of IBM SPSS 20 for windows software on the data value of students' process skills. The decision criteria used both homogeneity of variance together or individually are if the significance value is greater than 0.05 , then $\mathrm{HO}$ is accepted. If it is not homogeneous, then one of the variables is transformed into a log or root form.

The homogeneity hypothesis in this study is:

H0 : homogeneous / equal variance between groups

H1 : the variance between groups is not homogeneous / not the same

Normality test is used to determine whether the data is normally distributed or not. Normality test is carried out on students' process skills data both before and after treatment in each sample group. Normality test is carried out using a univariate approach, namely by conducting the Kolmogorov-Smirnov test with the help of IBM SPSS 20 software for windows at a significance level of $5 \%$. The decision criteria used are if the significance value is greater than 0.05 then $\mathrm{H} 0$ is accepted.

The hypothesis of the normality test is as follows:
H0 : the sample comes from a normally distributed population

$\mathrm{H} 1$ : the sample is not from a normally distributed population

The dependent variable in this study is the process skills and scientific attitude of students. The two dependent variable data were collected into two groups, namely the treatment class with the Modified Free Inquiry approach and the control class with the Guided Inquiry approach. Under these conditions, the statistical test that will be used in the form of multivariate analysis using the help of IBM SPSS 20 for Windows software on the posttest value.

The steps of hypothesis testing are carried out by multivariate analysis test to determine the null hypothesis and alternative hypotheses. The first hypothesis: (1) H0: there is no effect of the Modified Free Inquiry approach to the science process skills of students. (2) H1: there is an influence of the Modified Free Inquiry approach to students' science process skills. The second hypothesis: (1) H0: there is no effect of the Modified Free Inquiry approach to the scientific attitude of students. (2) H1: there is an influence of the Modified Free Inquiry approach to the scientific attitude of students

Steps to determine the value of significance and decision making: (1) Significance> 0.05 , so H0 is accepted, (2) Significance $<0.05$, so $\mathrm{H} 0$ is rejected

The effectiveness of the learning approach is determined based on the effectiveness index. Based on the completeness criteria of learning science at school that students are said to complete learning on the material system of the human senses if it reaches a minimum value of 6.8 for a scale of 10 or 68.00 for a hundred scale $(>70 \%$ of students in a group exceeds the minimum value). The criteria for achieving learning objectives are set at more than 68.99 based on an agreement between the researcher and the teacher of Natural Sciences in Biology class XI MAN Maguwoharjo. 
The effectiveness hypothesis is: (1) H0: $\mu 1$ $\leq 68.99$ (The Modified Free Inquiry Approach is not effective in terms of science process skills). H1: $\mu 1>68.99$ (Modified Free Inquiry approach is effective in terms of science process skills), (2) H0: $\mu 2 \leq 68.99$ (Guided Inquiry approach is not effective in terms of science process skills). H1: $\mu 2>68.99$ (Effective Guided Inquiry Approach in terms of science process skills).

Furthermore, one sample $t$ test was performed using the help of IBM SPSS 20 for Windows software to determine the effectiveness of each learning approach to critical thinking skills. The test criterion is that $\mathrm{HO}$ is rejected if the significance is less than 0.05 .

\section{Research Results and Discussion}

Table 1. Results of Student Process Process Skills

\begin{tabular}{cccccc}
\hline & & \multicolumn{2}{c}{ Approch } & \multicolumn{2}{c}{ Approch } \\
No & Description & Modified Free Inquiry & \multicolumn{2}{c}{ Guided Inquiry } \\
& & Before & After & Before & After \\
\hline 1 & Mean & 13,96 & 14,52 & 12,36 & 13,90 \\
2 & Median & 14,00 & 15,00 & 13,00 & 13,50 \\
3 & Modus & 13 & 15 & 13 & 13 \\
4 & Standard & 1,34 & 1,72 & 1,99 & 2,02 \\
& Deviation & & & & \\
5 & Varians & 1,81 & 2,95 & 3,96 & 4,08 \\
6 & Maksimum & 16 & 18 & 15 & 17 \\
7 & Minimum & 11 & 12 & 8 & 11 \\
\hline
\end{tabular}

\section{Description of Process Skills Observation Sheet}

The data shown in the table. 2 this is data on all aspects of process skills observed with an observation sheet, but have not

been specified based on each aspect separately.

Table 2. Results of Process Skills Observation Sheet

\begin{tabular}{|c|c|c|c|c|c|}
\hline \multirow[t]{2}{*}{ No } & \multirow[t]{2}{*}{ Description } & \multicolumn{2}{|c|}{$\begin{array}{c}\text { Approch } \\
\text { Modified Free Inquiry }\end{array}$} & \multicolumn{2}{|c|}{$\begin{array}{c}\text { Approch } \\
\text { Guided Inquiry }\end{array}$} \\
\hline & & Before & After & Before & After \\
\hline 1 & Mean & 43,38 & 45,35 & 42,81 & 43,81 \\
\hline 2 & Median & 43,00 & 46,00 & 42,00 & 43,00 \\
\hline 3 & Modus & 44 & 45 & 42 & 43 \\
\hline 4 & $\begin{array}{l}\text { Standard } \\
\text { Deviation }\end{array}$ & 6,43 & 6,43 & 5,15 & 5,15 \\
\hline 5 & Varians & 4,14 & 4,23 & 3,96 & 4,08 \\
\hline 6 & Maksimum & 55 & 55 & 49 & 42 \\
\hline 7 & Minimum & 26 & 26 & 30 & 27 \\
\hline
\end{tabular}




\section{Description of Process Skills Observation Sheet}

Data listed in the table. 3 This is data on all not been specified based on each form of aspects of the scientific attitude of students attitude display separately. observed with an observation sheet, but has

Table 3. Results of the Scientific Attitude Observation Sheet

\begin{tabular}{cccccc}
\hline No & Description & \multicolumn{2}{c}{ Approch } & \multicolumn{2}{c}{ Approch } \\
& & Modified Free Inquiry & \multicolumn{2}{c}{ Guided Inquiry } \\
& & Before & After & Before & After \\
1 & Mean & 7,78 & 12,43 & 7,32 & 8,04 \\
2 & Median & 8,00 & 13,00 & 7,00 & 8,00 \\
3 & Modus & 8 & 13 & 7 & 8 \\
4 & Standard & 1,35 & 1,50 & 1,13 & 1,32 \\
& Deviation & & & & \\
5 & Varians & 1,814 & 2,26 & 1,28 & 1,75 \\
6 & Maksimum & 10 & 14 & 8 & 10 \\
7 & Minimum & 5 & 8 & 5 & 6 \\
\hline
\end{tabular}

\section{Description of Questionnaire Results}

Data listed in the table. 4 This is a student questionnaire data sheet, this questionnaire data is more highlighted in the measurement of aspects of scientific attitudes and is more like a secondary data / supporting sheets of observations of students' scientific attitudes.
Data recorded in the table. 4 This is data on all aspects of scientific attitudes of students obtained from questions obtained by using a Likert scale questionnaire sheet with the category Always, Often, Rare, and Never. However, the questionnaire data has not been specified based on each response in the form of individual student attitudes

Table 4. Results of the Scientific Attitude Questionnaire Sheet

\begin{tabular}{|c|c|c|c|c|c|}
\hline \multirow[t]{2}{*}{ No } & \multirow[t]{2}{*}{ Description } & \multicolumn{2}{|c|}{ Approch } & \multicolumn{2}{|c|}{$\begin{array}{c}\text { Approch } \\
\text { Guided Inquiry }\end{array}$} \\
\hline & & Before & After & Before & After \\
\hline 1 & Mean & 30,34 & 54,56 & 29,65 & 43,65 \\
\hline 2 & Median & 52,32 & 61,00 & 51,64 & 55,00 \\
\hline 3 & Modus & 52 & 56,00 & 51 & 55,00 \\
\hline 4 & $\begin{array}{l}\text { Standard } \\
\text { Deviation }\end{array}$ & 3,23 & 3,55 & 2,97 & 3,16 \\
\hline 5 & Varians & 11,53 & 12,62 & 11,27 & 12,39 \\
\hline 6 & Maksimum & 43 & 52 & 42 & 49 \\
\hline 7 & Minimum & 41 & 64 & 38 & 54 \\
\hline
\end{tabular}

\section{Pre-Test Data Normality Test Results}

Normality test on the results of the pre-test data was carried out with the help of the IBM SPSS 20 for windows program in the form of the Kolmogorov-Smirnov test at a significance level of 0.05 .

Table 5. Pre-test Data Normality Test Results

\begin{tabular}{cccc}
\hline Groups & df & Significance & Information \\
Treatment & 23 & 0,64 & Data is normally distributed \\
Control & 22 & 0,77 & Data is normally distributed \\
\hline
\end{tabular}


The results of the analysis in table 5 conducted with the help of IBM SPSS 20 for windows software indicate that the significance value obtained by both samples is greater than 0.05 , the treatment

\section{Post-Test Data Normality Test Results}

Normality test on the results of the posttest data was carried out with the help of the IBM SPSS 20 for windows program in class has a significance value of $0.64>\alpha=$ 0.05 , and control class has a significance value of 0.77 , this can be interpreted that $\mathrm{HO}$ is accepted which means the data obtained are normally distributed

the form of the Kolmogorov-Smirnov test at a significance level of 0.05 .

Table 6. Post-test Data Normality Test Results

\begin{tabular}{cccl} 
Groups & df & Significance & Information \\
Treatment & 23 & 0,105 & Data is normally distributed \\
Control & 22 & 0,083 & Data is normally distributed \\
\hline
\end{tabular}

The results of the analysis listed in table 6 conducted with IBM SPSS 20 for windows software indicate the significance value obtained by the two sample groups is greater than 0.05 , the treatment class has a

\section{Homogeneity Test Results for Pre-Test Data}

Homogeneity test on the results of the pretest data was also carried out with the help of IBM SPSS 20 software for windows in significance value of 0.105 , and the control class obtains a significance value of 0.083 . From this fact, this can be interpreted that $\mathrm{HO}$ is accepted which means the data obtained are normally distributed.

the form of a Levene test at a significance level

of

0.05

Table 7. Homogeneity test results of pre-test data

\begin{tabular}{ccccc}
\hline Uji Levene & df1 & df2 & Significance & Information \\
1,094 & 1 & 43 & 0,301 & Data is homogeneous \\
\hline
\end{tabular}

The results of the analysis in table 7 . performed with IBM SPSS 20 for windows software shows that the significance obtained is 0.301 or greater than 0.05 . This

\section{Homogeneity Test Results Post-Test Data}

Homogeneity test on the results of the posttest data was also carried out with the help of the IBM SPSS 20 for windows program means that the data obtained has variance between groups that are the same / homogeneous.

Table 8. Results of post-test data homogeneity test

\begin{tabular}{ccccc}
\hline Uji Levene & $\mathrm{df}$ & $\mathrm{df} 2$ & Significance & Information \\
0,064 & 1 & 43 & 0,178 & Data is homogeneous \\
\hline
\end{tabular}

The results of the analysis in the table. 8 conducted with the help of IBM SPSS 20 software for windows shows the significance value obtained by 0.178 is greater than 0.05 . This means that the data 
obtained has variance between groups that

are the same / homogeneous.

\section{Hypothesis Test Results with Multivariate Analysis}

Hypothesis testing in this study uses a multivariate analysis test, where 2 dependent variables can be directly measured to determine the implementation

of the biological learning approach in the form of Modified Free Inquiry as a treatment group and Guided Inquiry as a control group.

Table 9. Hypothesis Test Results with Multivariate Analysis

\begin{tabular}{|c|c|c|c|c|c|c|c|}
\hline No. & & Approch & Mean & $\begin{array}{c}\text { Standard } \\
\text { Deviation }\end{array}$ & $\mathrm{N}$ & $\mathrm{df}$ & Sig. \\
\hline 1 & \multirow[t]{2}{*}{$\begin{array}{l}\text { Process } \\
\text { Skills }\end{array}$} & $\begin{array}{l}\text { Modified Free } \\
\text { Inquiry }\end{array}$ & 13,96 & 1,718 & 23 & 43 & 0,000 \\
\hline \multirow{3}{*}{2} & & Guided Inquiry & 13,91 & 2,022 & 22 & & \\
\hline & \multirow[t]{2}{*}{$\begin{array}{l}\text { Scientific } \\
\text { attitude }\end{array}$} & $\begin{array}{l}\text { Modified Free } \\
\text { Inquiry }\end{array}$ & 12,43 & 1,502 & 23 & 43 & 0,000 \\
\hline & & Guided Inquiry & 7,32 & 1,323 & 22 & & \\
\hline
\end{tabular}

From the table. 9 can be explained that the variable process skills and scientific attitude of participants have the same significance value, which is equal to 0,000 or less than 0.05 . From the significance value it can be concluded that there is an influence on the implementation of the approach to science process skills and scientific attitudes of students.

\section{Learning Mastery Test Results}

Learning is said to be complete when $68.99 \%$ of students meet the Minimum Mastery Criteria.

Table 10. Learning Mastery Test Results

\begin{tabular}{cccc}
\hline Approch & \multicolumn{3}{c}{ Test Value $=68,99$} \\
& $\mathrm{~T}$ & Df & Sig (2-tailed) \\
Modified Free Inquiry & 4,431 & 22 & 0,000 \\
Guided Inquiry & 0,745 & 21 & 0,464 \\
\hline
\end{tabular}

Table. 10 provides an explanation that the significance value of the Modified Free Inquiry approach is $\mathrm{Sig}=0.000<0.05$ which means that $\mathrm{H} 0$ is rejected and it can be stated that biology learning with the Modified Free Inquiry approach has been carried out effectively in terms of the science process skills of students, as well as the significance value of the Guided Inquiry approach is $\mathrm{Sig}=0.464>0.05$ which means that $\mathrm{HO}$ is accepted and it can be stated that biology learning with the Guided Inquiry approach has not been carried out effectively yet not significantly in terms of students' scientific process skills

\section{Discussion}

The process skills in the two sample groups in terms of the ability to define the nature and parameters of the problem are good and quite good, the absence of students in the very good category can be interpreted that students still need to explore more references / sources related to the material / problem being faced with. Related to this, some students actually have enthusiasm and are diligent in exploring information when learning takes place by browsing the internet via mobile phone, but something that is done in a short time without being based on prior knowledge makes these students incomplete in understanding the terms that 
are just found, so the students become hesitant when they want to answer the problem, express an opinion or refute a statement that is not appropriate. The existence of students who have high enthusiasm in learning needs to be supported by a partner who is able to assist both when studying in class and when studying independently.

The majority of classifying skills are mastered by students. This can be indicated because the material on the structure of the sensory system in humans is almost all discussed in the references that guide students. The manuals and workbooks clearly show the structural forms of each sense organ.

Some students related to predicting skills fall into the very good category, some others are divided into good and fairly good categories. This shows that students already have experience in predicting events that will occur. An assumption or suspicion that is appropriate to the phenomenon that occurs can be caused by students having experienced a similar event or just knowing about a theory / treasury of science even though the answer to the suspicion experienced is not yet exactly in accordance with the facts that should have occurred.

The thing that needs to be highlighted related to observations on the skill of making hypotheses is the presence of several students who are included in the good turtle category. Several reasons emerge from students' statements, namely that they are forgotten about the definition of a hypothesis and the form of a hypothesis sentence. Some students feel the need to be given a re-explanation of the understanding and the way a hypothesis sentence is arranged.

The skill to identify variables also shows students who do not know the meaning of a variable for an activity that applies the scientific method. When the notion of variables is unknown, an explanation of this needs to be elaborated until students understand the difference between the independent variable and the dependent variable and how to correlate it.

The skill of conducting experiments is at the core of scientific inquiry activities, therefore this aspect of skills is observed with the help of a special observation sheet in the form of a checklist to observe in more detail the sequences of the implementation of experimental / observation activities. This form of preparation of tools and materials, the implementation of steps / procedures, the treatment of objects, to pour data on monitoring / observation in the form of a portfolio which will later be the material for preparing official reports of activities. The observations show that the aspects of the skills in conducting this experiment have been successfully mastered by student participants. In its implementation, students seemed to enjoy the course of activities carefully and compactly for each group. Even so, students who still depend on the performance of their group mates still exist. Regarding this matter, it can be assumed that not all students carefully read the procedure of implementing activities, so that in some cases this sometimes causes repetition of activities.

The aspect of collecting data shows equitable results, in the sense that students are divided into each category, except in the bad category. Students who are classified as independent or very good generally become leaders in each group that is created. This is useful to be able to motivate other group members to be more enthusiastic about the activities. However, the presence of students in the very good category sometimes also causes dominance and is the reason other group members rely on the acquisition of scientific performance findings data on one person.

The existence of students who depend on the acquisition of data results on other group members should be reduced, because this will also reduce the level of experience and cruising levels of students at the next stage of the scientific 
performance process. In addition, the existence of dominant students and students who depend on the findings of other friends' data can cause gaps and ignorance in the process of processing the finding data into a conclusion that can be understood by all students, both within the scope of their groups and when delivering results in front class.

The aspects of making tables and graphics skills become aspects that appear to need to be developed more optimally. In these two aspects, there are still quite a lot of students who do not complete the findings data in a table and graph. Some participants seem to still think that tables and graphs are not the main problem in reviewing the results of the data. In fact, this can actually reduce the fluency to produce data and process it in more detail in the discussion and obtain conclusions from the results of more focused activities. The skill of organizing this data is quite affected by the activity of collecting data. Students who collect data independently announce that they will be able to organize data better according to the order of delivery, and details of small matters are not left out. Data that are better organized will make the results of activities easily understood by both students themselves and others. The observations show that students have coherently, but not yet optimal in terms of the completeness of the content in the form of data supporting the results of activities.

After being explained again about the various definitions and types of variables, students can actually understand and apply them to activities related to the material of the sensory system. Some students seem to have been kind not to mix the variables with other things that are not related to the activity. Activity controlling the variables here is measured or observed by adjusting the theme of the activity, students determine the variables that are in the activity and the final result of the activity controlling this variable is the ability so that these variables are not affected by other contents contained in the material. Students are able to steadily study the variables that have been determined at the beginning of the activity to make it as a study material / problem that needs to be constructed, answered or completed into a knowledge based on experience.

The students' skills in interpreting data also need to be improved, this is reflected by the large number of students who fall into the unfavorable category. The skill in interpreting data is obviously very influenced by the independence of students when collecting data. When data is obtained with their own abilities, students generally know things that need to be elaborated more broadly on the questions that exist when the process of scientific work-based activities takes place.

The skills of interpreting data are also influenced by the opportunity of students to obtain sources relevant to the material being studied, students who only rely on manuals and student worksheets become limited and less extensive in conveying new knowledge. Students who easily get a reference source will trigger many questions that can increase the involvement of students in learning, both by asking questions, arguing, even to the point of giving a rebuttal and rectifying things that are not appropriate to be conveyed.

The observation sheet of students' process skills shows the results that the majority of students in the category are good enough in terms of summarizing the results of activities. These results need to get attention so that students are able to perform better in the next activities. Learners need to reduce doubts and increase focus in concluding so as to be able to express the results of activities with simple sentences and cover the core activities. A good conclusion is shown by the style of discussion that is not longwinded and directly answer the problem that is trying to be solved and the answer is known. 
The imperfections in making tables and graphs as well as the cohesiveness when discussing problems in small groups and in front of the class, make aspects of communicating the results not yet optimal. When delivering the results of activities in front of the class, active students generally only get the task as a moderator and one person who is dominant in terms of presenting results, answering questions, and giving a rebuttal. Students who are good at communicating results generally make better portfolios so that they are able to master more deeply.

Related to various aspects of scientific attitudes of students observed, the treatment group / treatment where biological learning in the material sensory system in humans is done with the Modified Free Inquiry approach seems to have a scientific attitude that is superior to the control group that implements the Guided Inquiry approach. The existence of guidance from an educator makes students more focused on the directions conveyed and the emergence of pure ideas is less because the things students must do are clearly defined.

The honesty domain in the treatment group was slightly better than in the control group. Some students in the treatment group / treatment included in the very good category, while the control class seemed to dominate in the quite good category. It is probable that students rely on the elaboration of the material or the form of guidance conducted by educators, so that in some cases students imitate the performance performed by their peers.

The domain of curiosity in the treatment group also seems to be better, new things faced by students and the lack of guidance from educators makes students more creative in processing their imagination and optimizing their exploratory explorations. each. Learners make questions in themselves into a material to increase knowledge and answer the problems faced. Curiosity makes students more have a greater role in learning activities because there are problems that have not been resolved, want to share experiences on the knowledge gained, and so on.

The open minded domain (attitude openness) is observed both when students interact in their own groups and when communicating in front of the class. This domain in the treatment group shows better results, some students are categorized very well which means students want to respond to the character, opinions, input of others with full openness. In the control group several incidents still held to the direction of the educator and insisted on maintaining it. In fact, in this case students have actually been given the freedom to act in accordance with their own creativity and language style even though it must still be adjusted to the procedure of the activity.

The domain of skepticism in the treatment group also appears to be better than in the control group. The absence of guidance from an educator makes students careful in carrying out activities to fit the procedure and obtain results that are answers to the problems given. In the control group again relying instead on the guidance of an educator at each step of the activity, students ask for steps without reading the worksheet that has been given. Student questions in the control group are not a display of critical attitude.

From various results of the data obtained according to the implementation of implementation in the classroom, basically learning biology with the Modified Free Inquiry approach has advantages compared to learning biology with the Guided Inquiry approach, including: (1) Students are purer in exploring investigative ideas, educators try as much as possible it is possible to explore the reasoning power of students only in the form of an indirect analogy to the answer to a scientific phenomenon. Unlike the Guided Inquiry approach where educators always guide at each step of an experimental / observation procedure. (2) 
Students are more likely to display a more varied scientific attitude because of the lack of guidance obtained. (3) Students must truly understand the procedure of experimental / observation activities perfectly in order to be able to minimize the level of error during the implementation of learning activities, and (4) Educators are not the sole informants of learning activities using the Modified Free Inquiry approach because students learn to explore his own ability so that it becomes the answer to the problem / science phenomenon that is given. Educators simply play a role when reflecting on the implementation of learning with this Modified Free Inquiry approach, that role is in the form of alignment of material concepts that are wrongly understood by students, and when providing information.

\section{Conclusions and recommendations Conclusion}

The Modified Free Inquiry approach influences students' process skills with a significance acquisition of 0,000 . Thus, the Modified Free Inquiry approach can be said to be suitable to be applied because this approach is able to reduce the role of educators as sole informants and too dominant in learning.

The Modified Free Inquiry approach appears to influence the scientific attitude of students with a significance acquisition of 0,000 . The lack of role and guidance of educators in learning activities, in fact triggers the ability of students to construct / build original ideas possessed into a new experience that is explored in the form of performance in a learning.

\section{Recommendations}

Modified Free inquiry approach can be applied in a learning activity based on scientific performance, educators need to first strive for the emergence of original ideas or ideas in learners themselves and the determination of the completion steps that are arranged independently and systematically, so that the delivery of information directly does not take place in one direction from an educator and only in the form of reflection or a review of the conclusions of students who are not yet right.

Educators in conveying the material of the sensory system to humans are not only focused on one type of sensory device (by always designing the activity of observing the influence of blind spots on the eyes in each school year), but rather covering the whole type of sense devices in humans by dividing the class into several groups that examines the material of the different senses.

Increasing the intensity and variety of parenting educators in implementing learning approaches with scientific performance based activities so that the discipline of students in terms of utilizing implementation time and completing the preparation of reports on scientific performance based activities can also be improved.

\section{Bibliography}

Bundu, Patta. (2006). Penilaian Keterampilan Proses dan Sikap Ilmiah dalam Pembelajaran Sains - SD (Jakarta : Depdiknas)

Chabalengula, Vivien Mweene dan Frackson Mumba. (Juni 2012). Promoting Biological Knowledge Generation Using Model-Based Inquiry Instruction, International Journal of Biology Education, Vol.2, Issue 1

Hardini, Isriani, dan Dewi Puspitasari, 2012, Strategi Pembelajaran Terpadu, Teori, Konsep, dan Implementasi (Yogyakarta: Familia)

Rezba, Richard J., Constance Sprague, Jacqueline T. McDonnough, Juanita Jo Matkins. (2007). Learning and Assessing Science Process Skills (Iowa : Kendall/Hunt Publishing Company 
Pillai, S. Kulasekara Perumal. (Desember 2012). An Analytical Study on Scientific Attitude of Higher Secondary School Students in Virudhunagar District, International Journal of Teacher Educational Research (IJTER), Vol. 1, No. 4.
Sund, Robert B., Leslie W. Trowbridge (1973) Teaching Science by Inquiry in the Secondary School, Second Edition (Ohio : Charles E. Merril Publishing Company). 